Chapman University

Chapman University Digital Commons

English (MA) Theses

Dissertations and Theses

Spring 5-31-2021

\title{
"A Mind of Metal and Wheels": Agrarian Ruralism in Joss Whedon's Firefly and J.R.R Tolkien's The Lord of The Rings
}

Christopher Hines

Chapman University, chines@chapman.edu

Follow this and additional works at: https://digitalcommons.chapman.edu/english_theses

Part of the Literature in English, British Isles Commons, Literature in English, North America Commons, and the Modern Literature Commons

\section{Recommended Citation}

Hines, Christopher A. "A Mind of Metal and Wheels": Agrarian Ruralism in Joss Whedon's Firefly and J.R.R Tolkien's The Lord of The Rings. 2021. Chapman University, MA Thesis. Chapman University Digital Commons, https://doi.org/10.36837/chapman.000227

This Thesis is brought to you for free and open access by the Dissertations and Theses at Chapman University Digital Commons. It has been accepted for inclusion in English (MA) Theses by an authorized administrator of Chapman University Digital Commons. For more information, please contact laughtin@chapman.edu. 


\title{
"A Mind of Metal and Wheels": Agrarian Ruralism in Joss Whedon's Firefly and J.R.R Tolkien's The Lord of The Rings
}

\author{
A Thesis by \\ Christopher A. Hines \\ Chapman University \\ Orange, CA \\ Wilkinson College of Arts, Humanities, and Social Sciences \\ Submitted in partial fulfillment of the requirements for the degree of \\ Master of Arts in English
}

May 2021

Committee in charge:

Justine van Meter, Ph.D., Chair

Joanna Levin, Ph.D.

Brian Glaser, Ph.D. 
The thesis of Christopher A. Hines is approved.

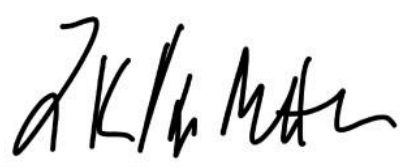

Justine van Meter, Ph.D., Chair

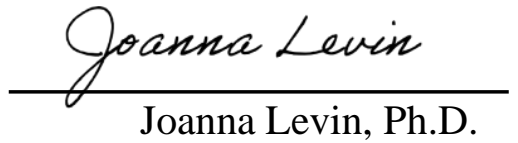

Brian Brodhead Glaser

Brian Glaser, Ph.D.

December 2020 


\title{
"A Mind of Metal and Wheels": Agrarian Ruralism in Joss Whedon's Firefly and J.R.R Tolkien's The Lord of The Rings
}

\author{
Copyright (C) 2020
}

by Christopher A. Hines 


\section{ACKNOWLEDGEMENTS}

First, I would like to thank Dr. Justine van Meter for agreeing to support me during the endeavor of writing this project, Dr. Brian Glaser for agreeing to join my committee even though he was on leave, and Dr. Joanna Levin for her invaluable help during what became an incredibly

difficult final year. I would also like to thank my family and friends who encouraged me to undertake this.

To my Tinúviel, a companion most fair, who provides endless comfort and unexpected inspiration. 


\begin{abstract}
"A Mind of Metal and Wheels": Agrarian Ruralism in Joss Whedon's Firefly and J.R.R Tolkien's

The Lord of The Rings

by Christopher A. Hines
\end{abstract}

Both Joss Whedon's Firefly and J.R.R Tolkien's The Lord of The Rings present settings that are just as much influenced by the environments in which they occur as they are by the characters who act within those environments. For J.R.R. Tolkien, it was his lived experience of having grown up in a changing England that influenced his depiction of the world, while Joss Whedon's Firefly revisits and readapts the American mythos of the Western and the cowboy and re-appropriates it to science fiction, placing the action in the far future and in space where humanity is once again exploring and settling new frontiers. In these stories, modernity and the advancement of technology and industry serve as a foil to the protagonists who live in bucolic agrarian rural zones. For Whedon, the threat manifests as the Alliance, a seemingly Orwellian government that rules from central worlds filled with vast cityscapes and seeks to impose its will upon the more agrarian outer worlds, who want to be free. With Tolkien, it is the ever industrializing Isengard and Mordor which serve as an existential threat to the peoples of Middle-earth. In both works, the rural and agrarian lifestyle is associated with freedom, peace, and goodness. In contrast, the modern and industrial is associated with tyranny, oppression, and the world's despoilment. Through examining the two texts with an ecocritical lens, one can see how cultural biases are reflected, constructed, and reconstructed through the vehicle of popular culture across the $20^{\text {th }}$ and $21^{\text {st }}$ centuries. 


\section{TABLE OF CONTENTS}

$\underline{\text { Page }}$

ACKNOWLEDGEMENTS ...........................................................................................

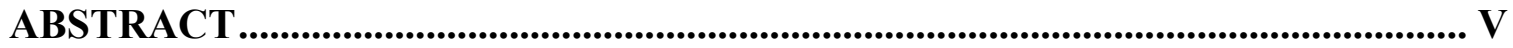

1 INTRODUCTION....................................................................................................... 1

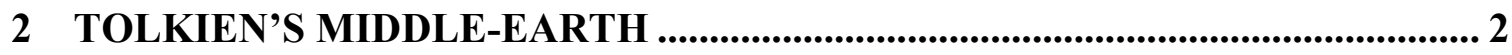

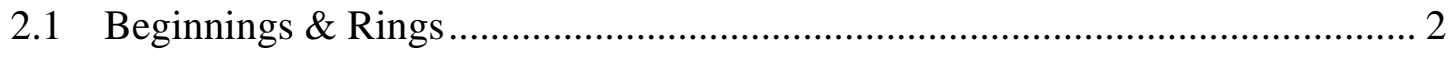

2.2 Industrialization \& Despoilation................................................................ 5

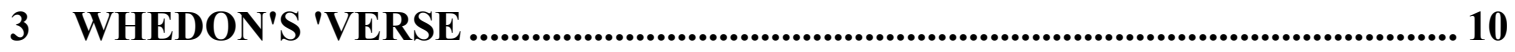

3.1 Reflecting \& Constructing of Cultural Biases .................................................. 10

3.2 Power \& Freedom .......................................................................................... 11

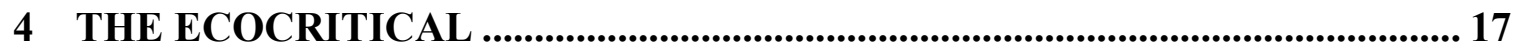

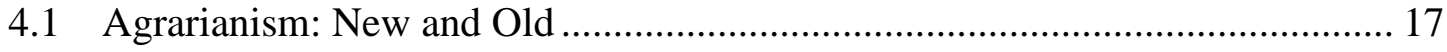

4.2 The Abjuration of Violence …………......................................................... 19

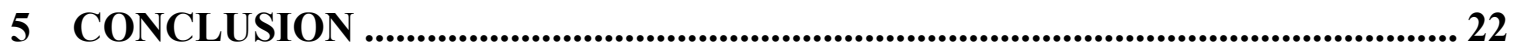

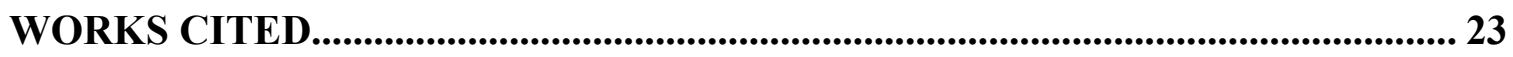




\section{Introduction}

Joss Whedon's Firefly and J.R.R Tolkien's The Lord of The Rings present settings that are as influenced by the environments in which they occur as they are by the characters who act within those environments. For J.R.R. Tolkien, it was his lived experience of having grown up in a changing England that influenced his depiction of the world, while Joss Whedon's Firefly revisits and readapts the American mythos of the western frontier and re-appropriates it to science fiction, placing the action in the far future and in space where humanity is once again exploring and settling new frontiers. In these stories, modernity and the advancement of technology and industry serve as a foil to the protagonists who live in bucolic agrarian rural zones. In Whedon's work, the depiction of the near Orwellian technologically advanced Alliance that dominates the core worlds is contrasted by the rural and rustic border moons and the individuals who inhabit them. The Alliance will stop at nothing to impose its will upon the border moons, who are ostensibly presented as wanting nothing more than to live free and simple lives. With Tolkien, it is the ever industrializing Isengard and Mordor which serve as an existential threat to the peoples of Middleearth. In both works, the rural and agrarian lifestyle is associated with freedom, peace, and goodness. In contrast, the modern and industrial is associated with tyranny, oppression, and the world's despoilment. While seemingly vastly different works, The Lord of the Rings and Firefly both serve as popular culture texts that mirror and influence cultural attitudes of both the $20^{\text {th }}$ and $21^{\text {st }}$ centuries, respectively. Considering that both texts have generated massive fanbases, both texts' cultural influence cannot be understated. Through examining the two texts with an ecocritical 
lens, one can see how cultural biases are reflected, constructed, and reconstructed through the vehicle of popular culture across the $20^{\text {th }}$ and $21^{\text {st }}$ centuries.

\section{Tolkien's Middle-earth}

\subsection{Beginnings \& Rings}

The works of Tolkien stand the test of time as some of the most widely read pieces of literature from the $20^{\text {th }}$ century. With several successful adaptations into film and other mediums, Tolkien's works remain prominent in the cultural consciousness of the world at large. Although Tolkien himself did not live during the time of the Industrial Revolution as it occurred in England, he was alive to see the immediate effects of such industrialization as well as the contrast of Agrarian life in the English countryside. As a child in the 1890s, J.R.R Tolkien lived in Sarehole, a rural and rustic area south of Birmingham, where he played with his brother and often frequented Sarehole Mill. Here, Tolkien enjoyed the freedom that a relatively agrarian lifestyle afforded him, and the happiness which he felt at Sarehole was one which he would carry along with him throughout his days. Indeed, much of his early imagination was cemented here (Carpenter 25-28). However, on the passing of his mother, Tolkien moved to Edgbaston in Birmingham. Here Tolkien developed his inspiration for Isengard and Mordor from his time spent beneath Perrot's Folly, an old tower. While the sky today is clear around Perrot's Folly, at the time of Tolkien's youth, the backdrop of industrial Birmingham would have been one of industrial smokestacks and chimneys billowing black smoke into the air. Under such conditions, it is easy to see how this location came to inspire Mordor and Isengard's despoiled lands. 
The influence of this childhood is apparent in The Lord of The Rings, with Tolkien describing the Hobbits of the Shire as folk that "love peace and quiet and good tilled earth: a well-ordered and well-farmed countryside was their favourite haunt. They do not and did not understand or like machines more complicated than a forge-bellows, a water-mill, or a hand-loom" (Tolkien, The Lord of the Rings V1.1.1-2). From the onset, it is established that the Hobbits are predisposed to a bucolic agrarian lifestyle, explicitly mentioning a disdain for complicated machinery. This is an important fact to show, as Hobbits often serve as the primary protagonist and narrative voice of Tolkien's story. It is Frodo, a mere Hobbit, who is chosen to carry the One Ring and who almost completes the journey before succumbing to its power. Others, such as Boromir, who are presented as unable to resist the proximity of the One Ring, say nothing of what would happen if he were to have carried it. It is interesting, then, that Hobbits are initially depicted as desiring for nothing more than to continue their idyllic lifestyle in the countryside.

Those who are tempted by the Ring, such as Isildur and Boromir, are all individuals who have strong desires. It seems to be that the influence of the One Ring is proportionate to the level of desire of those in proximity to it are corrupted. A desire to protect their people, a desire to serve some greater good, or mere avarice, as was the case of Sméagol and Déagol, are all enough to cause one to become corrupted by the influence of the Ring. The chief desire of most Hobbits in Tolkien's writing is either for adventure or for their homes. Even Gandalf, a servant of good, dares not take the One Ring, declaring, "Do not tempt me! For I do not wish to become like the Dark Lord himself. Yet the way of the One Ring to my heart is by pity, pity for weakness and the desire of strength to do good" (Tolkien, The Lord of the Rings V1.1.61). From this, we glean that even Gandalf, an agent of good in the world of Middle-earth, would be corrupted by the One Ring via his desire to do good. Likewise, while Hobbits usually are quite content with their lives, their 
resistance to the One Ring's influence is not total immunity. Notably, Bilbo and Frodo both feel the corrupting power of the Ring during their time with it. However, the rate of corruption in Bilbo and Frodo seems to take much longer than it does for Boromir. Ostensibly, this is due to Boromir's great need for the ring. His desire to protect the people of Gondor and to defeat Sauron makes Boromir further susceptible to the corrupting presence of the Ring.

Shippey's J.R.R. Tolkien: Author of the Century argues that in Medieval literature, "power reveals character" (114) rather than alters it, which is to say that Hobbits, who lack ambition and are content in their rural lives, are the least susceptible to the pressure of the One Ring. This theory is further supported by the fact that Tom Bombadil appears wholly immune to the influence of the One Ring and has absolutely no interest in it. Of Tom Bombadil, Tolkien writes, "He is master in a peculiar way: he has no fear, and no desire of possession or domination at all. He merely knows and understands about such things as concern him in his natural little realm" (Tolkien, The Letters of J.R.R. Tolkien 192). Again, we see that a being that is content in being who he is within his own little natural realm is not swayed by the One Ring in the slightest bit. 


\subsection{Industrialization \& Despoilation}

As a veteran, Tolkien saw first-hand the horrors of war and industrialization and the power and destruction which they wrought. The growth of civilization and the encroachment of technology and industrialization is ultimately responsible for the horrors perpetrated during the First World War. Smaller countries grew into more massive Empires that sought to undo and counteract one another, leaving a legacy of bloodshed and violence that Tolkien lived to see renewed in the Second World War. For Tolkien, there was an inherent connection between power and politics. Peter Critchley says that "Tolkien had a profound love for the Earth, and saw places as something distinct from, and more than, the political entities which sought to enclose them," and a letter reveals Tolkien had gone so far as to advocate for the dissolution of the United Kingdom (Critchley 110-111). It is no wonder, then, that Tolkien's Hobbit heroes desire little more than a simple life in the Shire, a geographic location with little to do with politics and which sought no power of its own. While Tolkien loved the bucolic peace he found in the countryside, he grew to disdain the political and grandiose after his time in The Great War. His aversion to technological advancements is also understandable, as the war saw the development of increasingly crueler ways to kill and destroy the world. The aftereffects of the First World War poisoned the land, rendering large swaths of land desolate and uninhabitable for generations to come, a problem which would be exacerbated by the Second World War. Just as Tolkien's childhood in the countryside modeled what he saw as good and heroic, his experience in the war and seeing industrialization's environmental devastation modeled his depiction of what was evil.

Likewise, we can see that in Tolkien's work, it is industrialization and the encroachment of technology that represents the destruction of a simpler way of life, a way of life that seems at its core to be inherently representative of freedom and goodness. For Tolkien, it is a notion that the 
ambition for bigger and grander things can be corrupting and destructive. To that end, the two towers of Mordor and Isengard are representative of evil precisely because they are interested in asserting dominion over the world, while it is the agrarian restfulness of the Hobbits which seems to render them resistant to the One Ring.

Saruman is evidence of a figure with great ambition who succumbs to the will of evil. More than ambition, Saruman also possessed envy and jealousy and coveted that which he could not have. Likewise, Sauron himself was ambition made manifest. He sought to rule the whole of Middle-earth and rose in power there from beneath the shadow of his overlord, Morgoth. Take, for instance, what transpires to the Shire at the hands of Isengard. Here we see the imposition of technology upon the Hobbits: "Take Sandyman's mill now. Pimple knocked it down almost as soon as he came to Bag End. Then he brought in a lot o' dirty-looking Men to build a bigger one and fill it full o'wheels and outlandish contraptions. Only that fool Ted was pleased by that, and he works there cleaning wheels for the Men, where his dad was the Miller and his own master" (Tolkien, The Lord of The Rings VI.5.1013). Once more, the concept of individual freedom is broached when discussing the miller and his son. While Ted's father was his own master, Ted is pleased by the technologically advanced mill the Men have brought to the Shire and works inside of it. This mirrors much of what happened in the wake of industrialization in England, where individuals who were once independent in the countryside soon became the employees of a larger entity. Indeed, many farms today are industrialized operations run by corporations rather than controlled by small families, as had once been the case. Shippey argues that "His is not the dragonsickness associated with gold, but it is a metal-sickness associated with iron" and that one sees this in "Saruman: it starts as intellectual curiosity, develops as engineering skill, turns into greed and the desire to dominate, corrupts further into a hatred and contempt of the natural world" (Shippey 
170). Likewise, it is only the evil forces in Tolkien's work that seems to utilize any advanced technology.

The forces of good in the form of Gondor and Rohan all use rather traditional and medieval manners of fighting, but when the Ents are besieging Isengard, we are told, "it was not long before he set some of his precious machinery to work... Suddenly up came fires and foul fumes: the vents and shafts all over the plain began to spout and belch. Several of the ents got scorched and blistered. One of them...got caught in a spray of some liquid fire and burned like a torch" (Tolkien 2004, 568). The language Tolkien uses in describing these events cannot help but draw the mind toward the First World War, where chemical gas attacks were frequent, and both sides fielded such monstrous weapons as the Flammenwerfer to deadly effect. Such means of killing were born precisely from the industrialized nature of warfare, as the First World War was one of the first major industrialized conflict. The changes in technology resulted in the front becoming stagnant, and increasingly inhumane means of killing were implemented to dislodge the enemy from their entrenchment. For example, John Garth notes, "At 7.20 a.m., ten minutes to every Zero Hour, every gun in the artillery accelerated to its maximum rate of fire in a hurricane bombardment" (153). Ultimately, even with all of his technology, Isengard cannot withstand the assault from the Ents, who are nature itself seeking revenge upon Saruman for his despoiling of the forests around Isengard.

Tolkien's writing seems to possess a hidden indication that the Earth itself will eventually come to rebuke those who rely on technology and despoil the land. Furthermore, such a cataclysmic event has occurred twice in the past of Middle-earth; as Matthew T. Dickerson and Jonathan D. Evans write in Ents, Elves, and Eriador: The Environmental Vision of J.R.R. Tolkien, "the Valar sweep across Middle-earth, destroy Morgoth, and split the northern world asunder, letting the sea 
roll in and change the shape of the western shores of Middle-earth forever. Another occurs at the end of the Akallabêth, when Ilúvatar drowns Númenor in recompense for its many offenses" (187). Similarly, Sauron's influence is more insidious and corrupting. The area which Mordor inhabited had once been beautiful and pristine but now is little more than a wasteland of production where Sauron builds his armies. However, upon the destruction of the ring the lands of Mordor were reclaimed as Barad-dûr and the Black Gate of Mordor collapse into states they would have existed in had Sauron not existed. On the matter of technology, Critchley writes, "Technology has power, the power to change and control things, and is therefore very seductive in its pull, and highly addictive in its possession" (Critchley 108). It is by the power of the ring that the corruption of Mordor is held in place, and by its destruction that the lands of Mordor are returned to nature.

In this regard, we can consider the One Ring of Power itself to be homologous with technology. Furthermore, Shippey postulates that any reader's doubt regarding the Ring's capabilities and Gandalf's warning "can be cleared up by one word, though it is not one that Tolkien uses, and was not recorded by the $O E D$ till its 1989 edition... 'addictive'. Gandalf's whole argument could be summed up as saying that use of the Ring is addictive" (Shippey 119). If technology is associated with power and thus with domination, then The Ring of Power itself is little more than a piece of technology made manifest in a different form. Likewise, it fits the qualities of being addicting in the way that it corrupts and compels those who possess it to use it. Critchley's description of technology and the description of the Ring complement one another in their means of operation and how they impact people; likewise, it fits Tolkien's understanding of power and the effects of power on the world, as well as the effects of technology in the destruction of the natural world.

This line of thought is supported by Tolkien's writing. Remembering that the Ring is a magic ring and therefore an inherently dangerous thing, we need only to look at Tolkien himself for an 
answer, "[b]y the last I intend all use of external plans or devices (apparatus) instead of development of the inherent inner powers or talents - or even the use of these talents with the corrupt motive of dominating: bulldozing the real world, or coercing other wills. The Machine is our more obvious modern form though more closely related to Magic than is usually recognized" (Tolkien Letters, 145). Here, in a letter, Tolkien describes a correlation between machine and magic in the ways and means in which they operate and the dominating and corruptive nature of both. Unsurprisingly, Saruman and Sauron are of the same order of beings, the Maiar, as Gandalf. The Maiar are powerful outsiders, a select few of these beings were sent to Middle-earth as the Istari, an order which was dedicated to combatting Sauron's influence, which Saruman led prior to his corruption. Even Gandalf was regarded with suspicion by some, especially among the Shire, where he was viewed as a menace due to the matter of Bilbo Baggins. The Istari, however, are more colloquially known in Middle-earth as Wizards, further blending the confusion of technology and magic in the presence of Saruman and his close utilization of both. 


\section{Whedon's 'Verse}

\subsection{Reflecting \& Constructing of Cultural Biases}

In Joss Whedon's Firefly, the worlds which exhibit the most individual freedom are the agrarian worlds located on the fringes of the Universe. In "The Alliance Isn't Some Evil Empire" Sharon Sutherland and Sarah Swan contend that Whedon "visually and thematically connects the postapocalypse worlds of dystopic film and the frontier plains of the Western. Combining the barren, open imagery of the two genres viscerally underlines the thematic links between two genres that examine the individual on the outer fringe of society" (90). Set in the aftermath of a civil war, the 'Verse, as it is called in-show, is divided between the so-called central planets where the Alliance is at its strongest and the border moons, who fought a war of independence against the Alliance and lost.

Whedon had neither the childhood experiences of Tolkien nor the experiences of war. Instead, Whedon's creation of Firefly was inspired fully by works of fiction which he had consumed. Amy Pascale writes that Whedon was inspired to write Firefly by Westerns produced in the 1970s: "He first conceived of the series when he wasn't supposed to be thinking about television at all, during a nonworking trip to London with Kai. Joss had brought along Michael Shaara's Pulitzer Prize-winning historical novel The Killer Angels" (Pascale 199). While Firefly was not inspired by a war that Whedon had personally experienced, it was inspired by the American Civil War. Pascale states, "What drew him in was how Shaara recounted the minutiae of the soldiers' lives; it made him think about how everyday people got by in an age when their needs weren't prepackaged and instantly available" (Pascale 199). This focus on the individual lives of people 
attempting to get by is mirrored in the life of the crew of the Serenity, a band of misfit outlaws who do what is necessary to survive. Given the unique space in which Whedon's work is situated, it is easy to say that Whedon's Firefly partakes both in reflecting cultural concepts as well as the construction and reconstruction of those ideas.

In Firefly, Whedon set out to create a science-fiction epic and was relatively successful at that. Focusing on the interpersonal lives of an ensemble cast, Firefly shows a group of individuals who are brought together by circumstance and who do what is necessary for their own survival, led by the captain Malcolm Reynolds, who only desires to keep his freedom and to keep his home flying. The story, however, is one with an inherently environmental message. From the onset of each episode, we are informed that Earth has been used up, and because of that, humanity set out to the stars to seek new worlds. Earth now lives in the memory of the people in the 'Verse as a mythological place, a veritable Garden of Eden which had been despoiled by the greed and corruption of humanity ("Serenity"). Furthermore, the Alliance is both a literal and figurative representation of the old world and the rampant consumerism which destroyed it, the Alliance wielding a flag consisting of a mashup between the United States of America and the People's Republic of China. While the Alliance's central worlds represent the mentality of industrialization and production, the border moons represent a pre-industrial life, where most people just want to be left alone to live their lives.

\subsection{Power \& Freedom}

The pilot episode of Firefly begins by introducing us to the end of a war for independence. Throughout the show, we see that the Alliance, the big government which the main character Malcolm "Mal" Reynolds and the Independents fought against, is expanding further out onto the 
fringes of space. This is commonly viewed with derision by Mal, who adopts a more libertarian view of things. Much in the way that Tolkien personally espoused a disdain for large governments and an appreciation for the rural and agrarian, Mal seeks to live his life as free from Alliance control as he can. With the war ending in defeat, Mal takes to the stars and the border moons, where Alliance control is shakier, and where society is more agrarian and rustic, than the central worlds where the Alliance is the dominant force. Much in a similar way that Frodo longs to return to the Shire he knew before he had to carry the ring to Mordor, Mal seeks a return to the agrarian and free life that the border moons offered before the imposition of Alliance rule.

We are shown that disdain for the Alliance extends beyond the crew of the Serenity when, in the episode "The Train Job" (2002), the gang robs a train of its shipment of medicine, and the Alliance troops refuse to help the small, agrarian town investigate the theft of the vital medication. As we learn in the episode, the town is a mining community. The stolen medicine is required for the people to survive the debilitating illness that the residents of the moon, even those who have never been in the mine, often catch. Mal, in response to the lack of Alliance assistance, remarks, "That sounds like the Alliance. Unite all the planets under one rule so that everybody can be interfered with or ignored equally" ("The Train Job"). Ultimately, by the end of the episode, Mal forsakes the crime lord he was employed by and returns the medicine to the town after he came to realize how serious the matter was. Rather than be punished for his initial theft of the medication, the Sheriff of the town only thanks him for making the right choice after seeing the situation.

From these two episodes, both of which are ostensibly first episodes for the show, as "Serenity" was a pilot and "The Train Job" was episode one, we can glean the show's tone. The Alliance is a corrupt government, a force that wants control for the sake of control and which does not aid those in need even if they are under their control. At best, the Alliance is negligent, and at worst, the 
Alliance is inherently corrupt and evil in Whedon's 'Verse. Their perverse desire for power and control drives them into the depths of experimenting on humans, as is the case of River Tam. Their callousness also leaves them to ignore the medicine's theft and carry on because it is a local problem. However, this is contrasted by the fact that in the episode "Serenity," the heroes are only able to escape by faking a distress signal, which pulls the attention of the Alliance patrol ship away from their illegal salvage.

Ultimately, we are not necessarily supposed to view the crew of the Serenity as heroes, but they are portrayed as heroic. They are criminals who do what they must in order to survive, but otherwise, they adopt a somewhat libertarian approach to life, letting people live as they wish. Amy Sturgis declares that Mal "has to live on the frontier of space because it is the only setting in which he can exercise his liberty" (Sturgis 27). Here, as we saw with Tolkien's Shire, Whedon's frontier space represents freedom and individual liberty.

On the frontier, the people want nothing more than to live their lives. There is no ambition or desire for power and control, but rather a wish to not be interfered with and to be allowed to live their lives as they choose. This is, of course, contrasted with the crew of the Serenity during the times in which they must visit the central systems where the Alliance is at its strongest. Of note, the further from the central systems one travels, the more technology seems to regress. Those who live on the systems deepest in the frontier are usually depicted as being small townships, using relatively primitive means of getting along. These worlds rely almost entirely on pre-industrial means of farming, production, and manufacturing. Much in the same way that the Shire has simple technology, the border moons have limited advancements, and the people seem happy to live their simple lives on the frontier. Indeed, many people that the crew of the Serenity encounter show 
little interest in politics on the larger scale, indifferent to whether the Alliance has control over them or not.

Fittingly, the Alliance in Whedon's Firefly is the most technologically advanced player at work throughout the show. Their technology allows them to project their power, and it is their technology that ultimately wins them the war against the Independents. It is revealed through the course of the show that the Alliance, in their pursuit of control and power, went so far as to experiment on living human children, tampering with River Tam's brain. It is unknown whether the changes they made activated a latent power in her or bestowed it upon her, but River Tam is the victim of technology and power run amok. In a show which idealizes libertarian freedoms in the agrarian frontier, what the Alliance does to River is the ultimate taboo. Without her consent, she is experimented on and deprived of her individual rights and freedoms. To the Alliance, she is a dangerous asset on the loose, which must be reclaimed at any cost. Moreover, the result of this experimentation seems to have left River with supernatural abilities She demonstrates the ability to read others' thoughts as the saga continues but lacks the agency to control even her own emotions following the experimentation. As seen in Tolkien's writing, technology and the supernatural seem to be entwined with one another.

When we are presented with the worlds which are under Alliance control, they are vast metropolises with advanced technology, but as is noted of the core world Ariel, "It's spotless, it's got sensors, and when there ain't sensors, there's Feds" ("Ariel"). To the crew of the Serenity, the Alliance represents oppression and technological surveillance. Here, on the core worlds, the Alliance uses its technology in the form of sensors to monitor everything. It is the ultimate surveillance state, with enforced curfews and districts which are considered problematic and offlimits to citizens. In the worlds dominated by the Alliance, merely going to the wrong place in a 
city makes someone a suspect. Likewise, it seems that wealthy Alliance loyalists often find themselves working on distant worlds where they live in luxury and exploit the land of its resources and the people of their labor. From this perspective, it is not hard to understand why Mal and Serenity view the Alliance with such disdain no more than it is hard to see why the Kingdoms of Gondor and Rohan and all the Free People's of Middle-earth oppose Saruman and Sauron. The Alliance in Firefly is, after all, the ultimate example of a big government that has gone too far and which oppresses and destroys the simpler way of life and independent freedom. While the Alliance is not actively conquering new planets, Firefly is more of a look at what happens when the fight is lost and living in the aftermath of a brutal civil war.

However, the criminal element which the crew of Serenity are members of is likely responsible for the oppressive state apparatus that the Alliance is portrayed as. While Sutherland and Swan note that " $[\mathrm{m}]$ ore than once, the Alliance members refer to Serenity and its crew as 'vultures' or describe them as picking off the bones of the dead" ("Empire" 92), the fact of the matter is that Mal and his crew were literally picking the remains of a colony ship like vultures. The surveillance state lamented against by the protagonists in "Ariel" is likely erected in response to anti-government sentiment in a nation recovering from a civil war, much in a similar vein as the South's military occupation following the conclusion of the American Civil War. Likewise, when Simon Tam rescues his sister River, he enlists the help of an underground cell, which indicates the presence of organizations working throughout the Alliance to subvert the government. Moreso, the medicine that is stolen but ultimately returned by Mal in "The Train Job" does not appear to have been a good which the Alliance were charging the colonists for. Instead, Mal takes on a job from a crime lord to steal the medicine so that the crime lord can sell it at a hefty profit and is doubly enticed to the job when he learns that he would be stealing from the Alliance directly. 
Likewise, the ostensible freedom provided of the agrarian world more often than not results in feudal serfdom where those less privileged are oppressed by bad actors. While Mal and his crew ultimately make the right choice to giver the medicine to the people, it is a choice that would have never been made if the crime lords weren't profiteering off of misfortune. In the 'Verse morality isn't as starkly black and white as it is presented in Tolkien's works, but the alliance is nevertheless painted in a villainous light.

Likewise, there is danger in the myth of the technological metropolis versus the agrarian rural. Often, the two systems are co-dependent upon one another and trying to showcase one above the other often misses the nuances and complexities of society and our interaction with the natural world. Yes, the Alliance has its share of demons, but it is also the Alliance and its technological splendor which allowed for the production and distribution of the medicine which had been stolen in the first place. Without that medicine, the residents of the moon would succumb to their horribly debilitating illness regardless of their rugged individualism and freedom, showcasing that technology isn't inherently corrupting and evil. The border moons, for however free they might appear, need the Alliance just as much as the Alliance needs them. 


\section{The Ecocritical}

\subsection{Agrarianism: New and Old}

To discuss the agrarian and ruralism depicted by Tolkien and Whedon, one also needs to consider what those authors are leaving out when they create these depictions. This sort of Romantic Pastoralism, as Greg Garrard (2011) writes, came about in the wake of the Industrial Revolution, privileging a "rural independence and fortitude that hides a harsh world in which people are bought and sold at hiring fairs" (Garrard 40) and American Pastoralism which seemed to "emphasise agrarianism, a political ideology associated with Thomas Jefferson that promoted a land-owning farming citizenry as a means of ensuring a healthy democracy" (Garrard 49). Furthermore, William Major in "The Agrarian Vision and Ecocriticism" finds that "we tend to mythologize and romanticize, tactics that are in so many ways an affirmation of our own despair over the course of modernity" (52) when looking at the agrarian. Indeed, Major champions the need for a new agrarianism finding that "the biocentric bias that has been a fundamental and necessary aspect of our conversation goes too far in abjuring human reason and desire as necessarily and always destructive" (56), instead noting that "[t]he supposition that we can save the land by idealizing it neglects the very foundation of life, of culture: the truth that we all do in fact live from and use the land" (59). In this sense, Tolkien and Whedon's work carries about them an air of romanticism that was typical of the early agrarian movements. For Tolkien, this seems to have developed from his own lived experiences in the changing of England between the $19^{\text {th }}$ and $20^{\text {th }}$ centuries, and for Whedon, the romanticizing of the agrarian is rooted entirely in the southern agrarian mythos which were transferred to him via the western books that inspired his construction of Firefly. While 
written in the $21^{\text {st }}$ century, the show maintains the vestigial attachment to those $20^{\text {th }}$-century notions by its source of inspiration. In this way, it can be seen how the cultural idea of agrarianism is reflected and simultaneously constructed by the popular culture that continues to circulate it.

As Major warns, "appeals to pristine nature are dangerous insofar as they obscure the violence that may have gone into the construction of their myths..." (Major 63) and "...we had better not romanticize what was lost in the process, lest we abjure our own history. Any response -- agrarian, romantic, biocentric -- is a cultural construction; it comes from somewhere" (Major 63-64). The cultural basis of the romanticization of the agrarian life in Tolkien and Whedon's work is essential as it solidifies its position in the broader cultural consciousness of human society, being both affected and later affecting the way in which environmental and agrarianism is depicted in popular culture. Indeed, Major's concerns are valid regarding the notion that an idealization leaves out the reality and obfuscates the reality of the agrarian life.

Dickerson and Evans raise the matter of stewardship in Tolkien's writing, noting that "Tolkien's model can best be described by the phrase Christian Stewardship. Here, we use the term stewardship strictly to mean the benevolent, selfless custodial care of the environment..." (xx), and while they make a compelling argument about Tolkien's idealistic notions of stewardship, Major finds that "[t]he idea that the land should be 'well-tended' implies that we are in some ways central to the right functioning of nature; stewardship and usufruct (the concept that we are merely borrowing nature and therefore must care for it) are key principles in this dynamic..."(62). Stewardship, while well intended, falls into the same traps of old agrarianism by being fundamentally anthropocentric. Stewardship views nature as something we are borrowing rather than something we are inherently apart of. Further, Major contends that "The point of agrarianism, therefore, is to highlight the connections between self and other so that we understand that what 
we do in one inevitably affects the other"(64). Rather than viewing nature as something separate from us that we have stewardship over. As is the case of Tolkien, the idea of stewardship lends itself to glorified imaginations of a pristine world that did not exist, and one which invites the abjuration of the history that went into the construction of that nature.

\subsection{The Abjuration of Violence}

For Tolkien, his stories glorify the agrarian lifestyle and seems to offer a warning about the misuse and overuse of technology and industrialization. While the natural world should be protected and revered, one must not become technophobic simply because one longs for a simpler time. Likewise, for Whedon, he tells a story inspired by the American Civil War: a narrative of a dystopic government run amok. In the years since the American Civil War, the idea that the war was primarily fought as a matter of state's rights has arisen, as did the refrain that the majority of

people who lived in the South were independent yeoman farmers. By removing the aspect of slavery from his Civil War inspired narrative, Whedon has run the risk of creating a glorification of the Confederate cause in the shape of his Browncoats, who really were just fighting for their individual rights in Firefly. While Whedon was influenced by The Killer Angels, that novel itself would no doubt have been influenced by the Southern Agrarian movement of the 1930s, described by Peter Nicolaisen as "belligerent Southerners; their focus was the South, its history, its institutions, and its special way of life... Southern Agrarians were part of a widespread movement of anti-industrialism" (Nicolaisen 683). The Southern Agrarians were a group that was interested in engaging in regionalism, their work often promoting the "lost cause" narrative of the Civil War.

Indeed, much work of popular fiction of the twenties, thirties, and forties was carefully constructed to depict the South as having been an agrarian paradise wherein the noble yeoman 
farmer contended with the interference of an authoritarian, industrialized power. In this dangerous fantasy, the Confederate States of America is presented as merely trying to preserve their southern way of life from the urban and industrialized north's encroachment. Nicolaisen notes that the journal which published the Southern Agrarians essays was an "avowedly right-wing, reactionary publication, whose owner and published, Seward Collins, made no bones about his Fascist preferences (Nicolaisen 685). Further notable is that the Southern Agrarians shared a common cause with agrarian National Socialist groups in Germany "[t]heir common intellectual background is that of the so-called "conservative revolution" with its criticism of progress, industrialism, and the applied sciences, its attacks upon the city, upon capitalism and the liberal political order...As was true of similar groups in Europe, the Southern Agrarians were regional in their thinking" (Nicolaisen 686). Here, the connection between Whedon and Tolkien becomes clearer. While it would be a stretch to say that Tolkien was a fascist in his views, he was a staunch conservative and a man who expressed similarly rationalistic tendencies, as noted in the earlier portion of this paper.

The danger in Whedon and Tolkien's work, then, is precisely what Major warns of in his essay. By creating romanticized depictions of the agrarian lifestyle that is grounded in nostalgia rather than actuality, both authors erase the historic violence that was prevalent in both systems. Tolkien's idyllic depiction of medieval life very neatly avoids the implications of feudalism, such as peasantry and serfdom, and the inherent class inequality present in aristocratic societies. In these depictions, Tolkien affords no thought to the immense human toll of feudalism, nor does he care to as what he is attempting to project is an idealized image of what the rural and agrarian life represented without acknowledging the very real deficiencies of said system. Likewise, Whedon's troubling engagement of a civil war narrative abjures the entire aspect of slavery and the countless 
years of inhumane suffering that was necessary to create that agrarian southern paradise. The closest acknowledgment given in the show is an offhanded remark about how Malcolm Reynolds was raised by farmhands. Still, the most egregious abuse in this narrative is probably the fact that the Alliance - ostensibly a stand-in for the Union in this lost cause narrative - seems to condone slavery, as shown in the episode "Jaynestown", where workers on a mud planet are referred to as property. The troubling implication here being that while Firefly isn't afraid to broach the subject of slavery it has removed the issue as central to the civil war narrative that it was inspired by. 


\section{Conclusion}

As Firefly and The Lord of the Rings have earned their places in the cultural zeitgeist of humanity, it is necessary to maintain a critical eye when examining them and the cultural messages they reflect and construct. Whedon's story offers the troubling depiction of civilization as evil when the protagonists of the story are literal criminals who stole medicine, medicine which seemed to be being given freely by the government to those suffering. Indeed, the heroic Browncoats are just as guilty of many crimes, some dating back to the war, as the Alliance. However, Mal and the crew of Serenity are still presented in a heroic light, and the Alliance is condemned as being all corrupt, power-hungry, and needlessly domineering. Likewise, it is hard to believe that the border moons in Firefly would somehow be worse off under the control of the central government than they were under the dominion of crime lords and corrupt barons who exploited them. It is essential to carefully consider the representation of what we receive in popular culture, as it is easy to get swept up in the nostalgia of the agrarian past and to forget that the injustices that were perpetrated under those systems were often just as cruel and corrupt as those enacted by society postindustrialization. A continued abjuration of the realities of the violence enacted in agrarian systems runs the risk of creating a sort of cultural feedback loop, wherein popular culture continues to construct and reconstruct a false idyllic image that transmits itself forward in the cultural zeitgeist and distorts the truth. 


\section{Works Cited}

“Ariel.” Firefly, created by Joss Whedon, season 1, episode 9, Fox Television, 2002.

Carpenter, Humphrey. J.R.R Tolkien: A Biography. Edited by J. R.R Tolkien, Houghton Mifflin Company, 2000.

Critchley, Peter. Tolkien and the Fellowship of All Living Things: The Politics of Proximity, Person and Place. Humanities Commons, dx.doi.org/10.17613/M6513TV47.

Dickerson, Matthew T. and Jonathan D. Evans. Ents, Elves, and Eriador: The Environmental Vision of J.R.R. Tolkien. University Press of Kentucky, 2006.

Garrard, Greg. Ecocriticism. Routledge, 2012.

Garth, John. Tolkien and the Great War: The Threshold of Middle-Earth. Houghton Mifflin, 2003.

Major, William. "The Agrarian Vision and Ecocriticism." Interdisciplinary Studies in Literature and Environment, vol. 14, no. 2, 2007, pp. 51-70.

Nicolaisen, Peter. "The Southern Agrarians and European Agrarianism.” The Mississippi Quarterly, vol. 49, no. 4, 1996, pp. 683-700.

Pascale, Amy. Joss Whedon: the Biography. Chicago Review, 2014.

"Serenity." Firefly, created by Joss Whedon, season 1, pilot, Fox Television, 2002.

Shippey, Tom. J.R.R. Tolkien: Author of the Century. HarperCollins Publishers., 2000.

Sturgis, Amy H. “'Them as Feel the Need to Be Free': Turner's Frontier Thesis." The Philosophy of Joss Whedon, edited by Dean A. Kowalski and S. Evan Kreider, Univ. Press of Kentucky, 2012, pp. 25-28.

Sutherland, Sharon, and Sarah Swan. "“The Alliance Isn't Some Evil Empire." Investigating Firefly and Serenity: Science Fiction on the Frontier, edited by Rhonda V. Wilcox, by Tanya R. Cochran, I.B. Tauris, 2008, pp. 89-100. 
Tolkien, J. R. R. The Letters of J.R.R. Tolkien. Edited by Humphrey Carpenter and Christopher Tolkien, Houghton Mifflin Harcourt, 2014.

Tolkien, J. R. R. The Lord of The Rings. Houghton Mifflin Harcourt, 2004.

“The Train Job." Firefly, created by Joss Whedon, season 1, episode 1, Fox Television, 2002.

Wilcox, Rhonda and Tanya R. Cochran. Investigating Firefly and Serenity: Science Fiction on the Frontier. New York, 2008. 